\section{$\underset{\substack{\text { hommes } \\ \text { \& migrations }}}{ }$}

\section{Hommes \& migrations}

Revue française de référence sur les dynamiques

migratoires

1305 | 2014

L'exil chilien en France

\title{
Ellis Island, histoire d'un rêve américain
}

Documentaire français de Michael Prazan

\section{Anaïs Vincent}

\section{(2) OpenEdition}

12 Journals

\section{Édition électronique}

URL : http://journals.openedition.org/hommesmigrations/2772

DOI : 10.4000/hommesmigrations.2772

ISSN : 2262-3353

\section{Éditeur}

Musée national de l'histoire de l'immigration

\section{Édition imprimée}

Date de publication : 1 janvier 2014

Pagination : 196

ISBN : 978-2919-040261

ISSN : $1142-852 X$

\section{Référence électronique}

Anaïs Vincent, «Ellis Island, histoire d'un rêve américain », Hommes \& migrations [En ligne], 1305 |

2014, mis en ligne le 16 juillet 2014, consulté le 22 septembre 2020. URL : http://

journals.openedition.org/hommesmigrations/2772 ; DOI : https://doi.org/10.4000/

hommesmigrations. 2772

Ce document a été généré automatiquement le 22 septembre 2020.

Tous droits réservés 


\title{
Ellis Island, histoire d'un rêve américain
}

\author{
Documentaire français de Michael Prazan
}

Anaïs Vincent

1 Face à la statue de la Liberté se dressent fièrement les imposants murs du centre fédéral d'immigration d'Ellis Island, aujourd'hui réhabilité en musée de l'immigration. Première étape d'une partie des nouveaux arrivants sur le sol américain, le centre a vu défiler de 1892 à 1954, date de sa fermeture, pas moins de douze millions d'immigrants ${ }^{1}$. Ils venaient d'Allemagne, d'Italie, de Russie... Anonymes et célébrités sont les témoins posthumes du dernier documentaire du réalisateur et écrivain Michael Prazan diffusé sur Arte. Se croisent les destins d'un jeune immigrant irlandais William O'dwyer, futur maire de New York, ou celui d'un garçon venu de Sicile, Salvatore Luciana, surnommé plus tard Lucky Luciano, qui deviendra l'un des ténors de la mafia italienne. Ou encore celui de la polonaise Barbara Apolonia Chałupiec, la célèbre actrice plus connue sous le pseudonyme de Pola Negri, égérie de Lubitsh et première star européenne a avoir fait carrière à Hollywood. On y rencontre aussi un autre migrant polonais, Samuel Goldwyn, non moins célèbre producteur américain. À travers leurs histoires émouvantes se bâtit en trois parties chronologiques un pan de la Grande Histoire du multiculturalisme américain. Quelle a été l'importance de ce centre dans cette construction? Cet entre-deux-mondes, lieu de transit, "usine à fabriquer des citoyens américains" selon Pérec continue de fasciner.

2 Depuis les premières images du centre par Edison en 1903, les cinéastes ont largement abordé ce sujet. On se souvient des Récits d'Ellis Island de Georges Pérec et Robert Bober en 1979 et d'Ellis Island de Meredith Monk. Island of Hope - Island of Tears de Charles Guggenheim 1989.

3 Il est aussi le théâtre de nombreuses fictions comme The Migrant de Charlie Chaplin, The Yellow Ticket de Raoul Walsh, America, America d'Elia Kazan, Le Parrain II de Copola, Golden door de Emanuele Crialese et, très récemment, The Imigrant de James Gray.

4 Les photos des migrants du centre de Lewis Hine et d'Augustus Frederick Sherman ont contribué à nourrir cet imaginaire collectif. Il cristallise à lui seul toute l'histoire de 
l'immigration américaine. Mais, par sa chronologie (1892-1954), par ses origines essentiellement européennes, ce lieu ne représente pourtant qu'une petite partie du flux migratoire.

5 Michael Prazan revient sur les événements qui jalonnent l'histoire du centre: l'évolution du contrôle des flux migratoires, les directions successives. Le destin romanesque de ces célébrités qui en ont franchi le seuil sont illustrées par de riches images d'archives et des reconstitutions malheureusement assez inutiles. Le tout entrecoupés d'interviews de spécialistes et accompagnée d'une musique racoleuse. Il réalise ainsi un film historique quelque peu académique.

\section{NOTES}

1. “'L'île de M. Ellis. Du dépôt de munitions au lieu de mémoire” in Hommes \& Migrations, $n^{\circ} 1247$, 2004 